\title{
Lymphocytic infiltration in the chicken trachea in response to Mycoplasma gallisepticum infection
}

\author{
J. E. Gaunson, C. J. Philip, K. G. Whithear and G. F. Browning \\ Author for correspondence: J. E. Gaunson. Tel: +613 8344 7371. Fax: +61383447374. \\ e-mail: j.gaunson@pgrad.unimelb.edu.au
}

School of Veterinary Science, University of Melbourne, Parkville, Victoria 3052, Australia

\begin{abstract}
A prominent feature of disease induced by Mycoplasma gallisepticum is a lymphoproliferative response in the respiratory tract. Although this is also seen in other mycoplasma infections, including Mycoplasma pneumoniae, the phenotype of the lymphocytes infiltrating the respiratory tract has not been determined. In this study, the numbers and distribution of lymphocytes in the tracheas of chickens infected with a virulent strain of $M$. gallisepticum were examined. Three groups of chickens were experimentally infected with $M$. gallisepticum and three unchallenged groups were used as controls. One infected and one control group were culled at 1, 2 and 3 weeks post infection. Tracheas were removed and examined for the presence and number of $T$ cells carrying CD4, CD8, TCR $\gamma \delta$, TCR $\alpha \beta 1$ or TCR $\alpha \beta 2$ markers. There was no significant difference in the number of $\mathrm{CDB}^{+}$cells in the upper, middle and lower trachea. High numbers of both $\mathrm{CD4}^{+}$and $\mathrm{CD8}^{+}$cells were found with variable numbers of TCR $\alpha \beta 1^{+}$and TCR $\alpha \beta 2^{+}$, but no TCR $\gamma \delta^{+}$, cells throughout the time course. The distribution of CD4 cells was dispersed, while the $\mathrm{CD8}^{+}$cells were clustered in follicular-like arrangements. No difference was detected in the distribution of TCR $\alpha \beta 1^{+}$and TCR $\alpha \beta 2^{+}$cells. The titre of mycoplasma genomes in the trachea decreased significantly from 1 to 2 weeks, while the mucosal thickness of the trachea increased significantly from 1 to 2 weeks then decreased from 2 to 3 weeks, indicating resolution of the lesions following control of infection. This study is the first to examine the phenotypes of $T$ lymphocytes infiltrating the respiratory tract during mycoplasma infections. The findings suggest involvement of specific stimulation of $\mathrm{CDB}^{+}$cells, particularly in the acute phase of disease.
\end{abstract}

Keywords: CD8, TCR $\gamma \delta$, mycoplasmosis, infiltration

\section{INTRODUCTION}

Mycoplasma gallisepticum is a major avian pathogen which causes chronic respiratory disease in chickens, leading to decreased productivity in both meat and egg production. The lesions produced in the respiratory tract of infected birds are similar to those caused by several other mycoplasmas, including experimental infections of laboratory animals by Mycoplasma pneumoniae (Cimolai et al., 1992), a common cause of community acquired pneumonia in humans.

Abbreviations: $\mathrm{MHC}$, major histocompatibity complex; pi, post infection; $\mathrm{RSA}$, rapid serum agglutination; RT, room temperature; $T C R$, T-cell receptor.
It is known that mycoplasmas initiate a variety of immune responses ranging from complement activation to ingestion by macrophages (Simecka et al., 1992); however the mechanisms by which they stimulate a chronic immune response, yet manage to avoid elimination from the host, are poorly understood. While the systemic and local antibody responses to $M$. gallisepticum have been studied (Avakian \& Ley, 1993; Chhabra \& Goel, 1980) cell-mediated immunity is also thought to play a role but has not been extensively investigated. Birds which lacked a fully functional immune system due to either neonatal bursectomy and/or thymectomy, showed an inability to clear $M$. gallisepticum from the trachea (Mukherjee et al., 1990) and demonstrated significantly increased lesion scores 
compared to normal birds (Tiwary \& Goel, 1986). This indicates that a fully functional humoral and, more importantly, cellular immune system is required to respond to, and recover from, M. gallisepticum infection.

Protection from Mycoplasma pulmonis infection has been found to be transferred by immune splenic lymphocytes (Lai et al., 1991), and a $\mathrm{CD}^{+} \mathrm{T}$ cell clone responding to Acholeplasma laidlawii membrane proteins is a further indication of a role of cellular immunity (Kuwano et al., 1997). It has further been shown that some Mycoplasma spp., such as Mycoplasma arthriditis, produce superantigens or mitogens that are capable of initiating $T$ cell responses (Cole $\&$ Atkin, 1991), although such a product has not been found in M. gallisepticum.

The current work aimed to investigate lymphocytic responses in the chicken trachea to $M$. gallisepticum infection. By staining for a variety of cell-surface markers it was hoped that the $\mathrm{T}$ cell populations infiltrating the trachea could be elucidated, providing further information about the role of cell-mediated immunity in response to this pathogen.

\section{METHODS}

M. gallisepticum strain and culture conditions. M. gallisepticum strain Ap3AS was grown in Frey's Modified Mycoplasma Growth Broth (Frey et al., 1968) at $37^{\circ} \mathrm{C}$ until late-exponential phase. The concentration of viable organisms used for challenge was $1.87 \times 10^{7}$ colour-changing units $\mathrm{ml}^{-1}$.

Chickens. Forty-seven, 15-week-old specific-pathogen-free White Leghorn chickens were purchased commercially and housed in five groups of eight and one group of seven in separate bubble isolators. The specific-pathogen-free flock was tested regularly for freedom from pathogenic mycoplasmas and a range of viruses including major respiratory pathogens and immunosuppressive viruses. Blood samples were taken from all chickens prior to infection and no antibodies against M. gallisepticum were detected by the rapid serum agglutination (RSA) test.

Experimental infection of chickens. Three groups of chickens were infected with $M$. gallisepticum and three uninfected groups were used as controls. One group of challenged and one group of control birds were killed with barbiturate at 1, 2 and 3 weeks after infection, at which time blood and tissue samples were taken.

Chickens were challenged by aerosol with M. gallisepticum for $10 \mathrm{~min}$ in an isolation chamber as described previously (Whithear et al., 1996). As previous studies have shown that exposure to media alone has no effect upon the respiratory tract (Whithear et al., 1996), control birds were left unchallenged.

Blood samples from all birds were tested by the RSA test for antibodies against $M$. gallisepticum and scored on a scale of 0 (no clumping) to 4 (large clumps with clearing of antigen suspension) (Whithear, 1993).

Preparation of tissue sections. At post-mortem the trachea, spleen, bursa and thymus were removed from each bird. Immediately following removal from the bird, the trachea was washed with $5 \mathrm{ml}$ sterile PBS, and washes were stored at $-20{ }^{\circ} \mathrm{C}$ until required. Approximately $5 \mathrm{~mm}$ sections of upper, middle and lower trachea were removed, placed in Tissue-Tek OCT embedding compound and immediately frozen in liquid nitrogen. Similarly sized sections of spleen, bursa and thymus were also frozen for use as control tissues.

The remaining tissue was then placed in $10 \%$ neutral buffered formalin and fixed for $24 \mathrm{~h}$. Tissues were then processed to paraffin and stained with haematoxylin and eosin.

Immunohistochemistry. Optimal conditions for immunohistochemical staining with each $\mathrm{mAb}$ were determined using spleen, bursa and thymus tissues. All mAbs stained cell populations in positive-control tissue with equal intensity. These tissues were included as controls during the staining of each group of slides. Frozen tissue blocks were cut into $5 \mu \mathrm{m}$ sections, transferred to Superfrost Plus slides (Menzel-Glaser) and stored at $-70{ }^{\circ} \mathrm{C}$ until staining. Just prior to staining, sections were fixed in acetone for $10 \mathrm{~min}$, washed with PBS and incubated with $\mathrm{mAbs}$ specific for $\mathrm{T}$ cell surface antigens for 45 min under the following conditions: mouse anti-chicken CD8 (Chemicon) at a dilution of 1:100 at room temperature (RT); mouse anti-chicken CD4 (Southern Biotechnology) at a dilution of $1: 1000$ at $37^{\circ} \mathrm{C}$; mouse anti-chicken TCR-1 $(\gamma \delta)$ (Southern Biotechnology) at a dilution of 1:5000 at RT; mouse anti-chicken TCR-2 ( $\alpha \beta 1)$ (Southern Biotechnology) at a dilution of $1: 1000$ at RT; mouse anti-chicken TCR-3 ( $\alpha \beta 2)$ (Southern Biotechnology) at a dilution of 1:100 at RT. Following primary antibody incubation, sections were washed in PBS and incubated with the secondary antibody, rabbit anti-mouse horseradish peroxidase conjugate (Chemicon), at a dilution of $1: 100$ at RT for $45 \mathrm{~min}$. Bound antibody was detected with 3,3'-diaminobenzidine (Sigma) and the slides were counterstained with haematoxylin and mounted with DPX (dibutyl phthalate, polystyrene granules and xylene) neutral mounting medium (Ajax). Positively stained cells were counted using an eyepiece micrometer and quantified as cells $(\mathrm{mm} \text { tissue })^{-2}$.

Histological examination. The mucosal thickness of the trachea of each bird was determined by measuring the thickness at four points transected by vertical and horizontal lines. An anterior and posterior segment was measured for each bird (Nunoya et al., 1987).

Extraction of mycoplasma DNA from tracheal washes. The DNA extraction method was adapted from Sykes et al. (1998) as follows. A $100 \mu \mathrm{l}$ sample of tracheal wash was mixed with $350 \mu \mathrm{l}$ RLT lysis buffer (Qiagen) containing 1\% 2-mercaptoethanol. The sample was then added to an equal volume of $70 \%$ ethanol, mixed, a $15 \mu \mathrm{l}$ aliquot of Qiaex II matrix (Qiagen) was added and the entire sample loaded onto a multispin column (Axygen) placed in a $2 \mathrm{ml}$ microfuge tube. The column was centrifuged at $9500 \mathrm{~g}$ for $15 \mathrm{~s}$ and the flowthrough discarded. The column was washed once with RLT buffer (Qiagen) and twice with RPE buffer (Qiagen) at $9500 \boldsymbol{g}$ for $15 \mathrm{~s}$. Following a final spin at $16000 \mathrm{~g}$ for $1 \mathrm{~min}$ to dry the column, the DNA was eluted through the addition of $30 \mu \mathrm{l}$ DEPC (diethyl pyrocarbonate)-treated water and centrifuging for $1 \mathrm{~min}$ at $9500 \mathrm{~g}$.

Detection of mycoplasma DNA. A 219 bp segment of the $M$. gallisepticum $16 \mathrm{~S}$ rRNA gene was amplified using primers MG1273f (5'-GTTGGCAAATCCGTAAGGTGG-3') and MG1427r (5'-TTAGCAACACGGTTTTAGAT-3') (Boyle \& Morrow, 1994). The PCR reaction was performed using $1.5 \mathrm{U}$ Taq DNA polymerase in a $50 \mu \mathrm{l}$ reaction mix containing $10 \mu \mathrm{l}$ DNA sample, $10 \mathrm{mM}$ Tris/HCl (pH 8.3), $1.5 \mathrm{mM} \mathrm{MgCl}_{2}$, 
Table 1. T lymphocyte concentrations in the tracheal mucosa of chickens infected with M. gallisepticum

ND, No data available.

\begin{tabular}{|c|c|c|c|c|c|c|c|}
\hline Bird no. & $\begin{array}{c}\text { Mucosal } \\
\text { thickness } \\
\quad(\mu \mathrm{m})^{*}\end{array}$ & RSA $†$ & $\mathrm{CD}^{+} \neq$ & $\mathrm{CD}^{+} \neq$ & $\mathrm{TCR}_{\gamma} \delta^{+} \neq$ & $\mathrm{TCR}_{\boldsymbol{\alpha} \beta \mathbf{1}^{+} \ddagger}$ & $\mathrm{TCR} \alpha \boldsymbol{\beta} 2^{+} \neq$ \\
\hline \multicolumn{8}{|c|}{ (a) 1 week pi } \\
\hline 338 & $139 \cdot 0$ & 0 & 19 & 13 & 0 & ND & ND \\
\hline 339 & $118 \cdot 0$ & 0 & 17 & 15 & 0 & 6 & 12 \\
\hline 340 & $161 \cdot 0$ & 0 & 8 & 10 & 0 & 0 & 15 \\
\hline 341 & $112 \cdot 0$ & 0 & 25 & 24 & 0 & 0 & 18 \\
\hline 342 & $132 \cdot 0$ & 0 & 21 & 15 & 0 & 0 & 14 \\
\hline 343 & $305 \cdot 0$ & 0 & 35 & 17 & 0 & 0 & 16 \\
\hline 344 & $222 \cdot 0$ & 0 & 31 & 29 & 0 & 47 & 17 \\
\hline 345 & $94 \cdot 0$ & 0 & 28 & 12 & 0 & 0 & 16 \\
\hline \multicolumn{8}{|c|}{ (b) 2 weeks pi } \\
\hline 346 & $355 \cdot 0$ & 3 & 30 & 10 & 0 & 7 & 20 \\
\hline 347 & $340 \cdot 0$ & 3 & 24 & 10 & 0 & 16 & 10 \\
\hline 348 & $135 \cdot 0$ & 3 & 10 & 8 & 0 & 6 & 0 \\
\hline 349 & $126 \cdot 0$ & 4 & 14 & 14 & 0 & 13 & 0 \\
\hline 350 & $335 \cdot 0$ & 3 & ND & 11 & 0 & 47 & ND \\
\hline 351 & $230 \cdot 0$ & 3 & 21 & 10 & 0 & 26 & 11 \\
\hline 352 & $401 \cdot 0$ & 3 & 34 & 14 & 0 & 14 & 8 \\
\hline 353 & $298 \cdot 0$ & 3 & 30 & 14 & 0 & 15 & 14 \\
\hline \multicolumn{8}{|c|}{ (c) 3 weeks pi } \\
\hline 323 & $252 \cdot 0$ & 3 & 26 & 19 & 0 & 16 & 8 \\
\hline 324 & $101 \cdot 0$ & 3 & 29 & 11 & 0 & 24 & 5 \\
\hline 325 & $321 \cdot 0$ & 3 & 22 & 17 & 0 & 0 & 9 \\
\hline 326 & $279 \cdot 0$ & 3 & 13 & 13 & 0 & 29 & 9 \\
\hline 327 & $90 \cdot 0$ & 3 & 44 & 11 & 0 & 11 & 10 \\
\hline 328 & $220 \cdot 0$ & 3 & ND & 11 & 0 & ND & 17 \\
\hline 329 & $329 \cdot 0$ & 3 & 8 & 23 & 0 & 12 & 35 \\
\hline 330 & $299 \cdot 0$ & 3 & 9 & 10 & 0 & 0 & 12 \\
\hline
\end{tabular}

* Mean mucosal thickness of an anterior and posterior segment of trachea. Thickness was measured at four points transected by vertical and horizontal lines.

† RSA of serum antibodies to M. gallisepticum was scored from 1 to 4 (Whithear, 1993).

$\ddagger \mathrm{CD} 4^{+}, \mathrm{CD}^{+}, \mathrm{TCR} \gamma \delta^{+}, \mathrm{TCR} \alpha \beta 1^{+}$and TCR $\alpha \beta 2^{+}$lymphocytes were counted and quantitated as cells $\mathrm{mm}^{-2}$ of tissue.

$50 \mathrm{mM} \mathrm{KCl,} 200 \mu \mathrm{M}$ each of dATP, dTTP, dGTP and dCTP, and $1 \mu \mathrm{M}$ each primer. Following an initial denaturation step at $95^{\circ} \mathrm{C}$ for $2 \mathrm{~min}$, the reactions were run for 40 cycles of $95{ }^{\circ} \mathrm{C}$ for $30 \mathrm{~s}, 55^{\circ} \mathrm{C}$ for $30 \mathrm{~s}$ and $72{ }^{\circ} \mathrm{C}$ for $30 \mathrm{~s}$.

The PCR products were analysed by gel electrophoresis on a $2 \%(\mathrm{w} / \mathrm{v})$ agarose gel containing $0.5 \times \mathrm{TPE}$ buffer and $0 \cdot 1 \mu \mathrm{g}$ ethidium bromide $\mathrm{ml}^{-1}$.

Each extracted DNA sample was amplified undiluted and at each of a series of five 10-fold dilutions to determine the limiting dilution for generation of a product. The mycoplasma genome titre was described as $\log _{10}$ of the highest dilution at which a PCR product was detectable.

Statistical analysis. Concentrations of positive cells were compared and analysed over time using a Mann-Whitney U test and between tracheal regions using one-way analysis of variance (ANOVA).
Changes in mucosal thickness and bacterial genome titre over time were analysed by a two-sample $\mathrm{T}$ test assuming equal variances. Comparisons of mucosal thickness were performed using all measurements on all birds at each time point rather than on the mean thickness for each bird (as shown in Table 1).

\section{RESULTS}

\section{Antibody response}

Antibodies against M. gallisepticum were not detectable at 1 week post infection (pi) (Table 1a) but strong RSA reactions were observed in all birds at 2 and 3 weeks pi (Table $1 \mathrm{~b}, \mathrm{c})$. No antibodies against $M$. gallisepticum were detected in any of the control birds at any of the time points. 


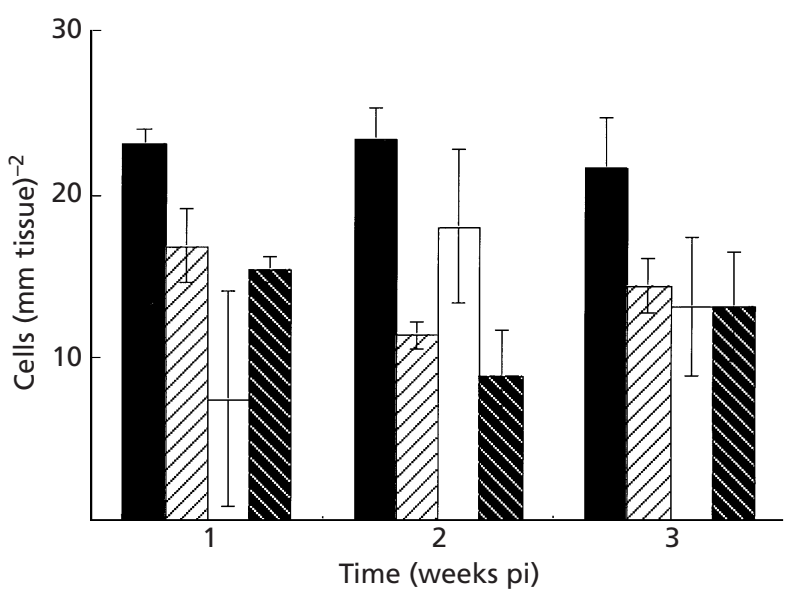

Fig. 1. Mean $T$ cell concentrations $\pm S E M$. Populations of $\mathrm{CD}^{+}$ (black bars), CD8 ${ }^{+}$(white hatched bars), TCR $\alpha \beta 1^{+}$(white bars) and TCR $\alpha \beta 2^{+}$(black hatched bars) cells in the trachea were measured at 1, 2 and 3 weeks pi with $M$. gallisepticum. No $\operatorname{TCR} \gamma \delta^{+}$cells were detected.

\section{Immunohistochemistry}

Tissue sections were stained for the presence of the $\mathrm{T}$ cell markers CD4, CD $8, \mathrm{TCR} \gamma \delta$, TCR $\alpha \beta 1$ and TCR $\alpha \beta 2$. No $T$ cells were detected in any sections from control birds by any of the cell-surface markers at any of the time points. In the first instance, tissue sections from the upper, middle and lower trachea were stained for $\mathrm{CD} 8^{+}$ cells at each time point. $\mathrm{CD}^{+}$cell concentrations at three sites along the trachea were compared using a oneway ANOVA. The concentrations along the trachea were not found to differ significantly at $1(P=0 \cdot 664), 2$ $(P=0 \cdot 106)$ or 3 weeks pi $(P=0 \cdot 456)$. As no significant difference was found between the concentration of $\mathrm{CD} 8^{+}$ cells at the different levels of the trachea, subsequent staining focused upon middle sections of trachea only.

Results of immunohistochemical staining for all infected birds at each time point are given in Table 1, and the results are summarized graphically in Fig. 1.

\section{Distribution of T-cell populations in tracheal mucosa}

The distribution of the different T-cell populations in the tracheal mucosa of infected birds was also examined. Whilst the $\mathrm{CD}^{+}$cells appeared scattered throughout the tissue (Fig. 2a), CD8 ${ }^{+}$cells were generally found in large clusters throughout the course of infection (Fig. $2 \mathrm{~b}$ ). These clusters were either large aggregates, in a follicular-like arrangement, or clusters bordering an area of thickening or swelling in the tracheal mucosa. Neither TCR $\alpha \beta 1^{+}$or TCR $\alpha \beta 2^{+}$cells showed uniform arrangements within the mucosa, appearing both as single cells scattered throughout the mucosa (Fig. 2d) and in aggregates of cells within follicles (Fig. 2c, d). The varied arrangement of these cells suggested that TCR $\alpha \beta 1$ and TCR $\alpha \beta 2$ occurred on both $\mathrm{CD} 4^{+} \mathrm{CD} 8^{-}$and $\mathrm{CD} 4^{-}$ $\mathrm{CD} 8^{+}$cells.

\section{Analysis of cell populations over time}

Cell populations were compared over time using the Mann-Whitney $U$ test. Populations which differed significantly over time were: $\mathrm{CD}^{+}$between 1 and 2 weeks pi $(P=0 \cdot 034)$; TCR $\alpha \beta 1^{+}$between 1 and 2 weeks pi $(P=0 \cdot 021)$; and TCR $\alpha \beta 2^{+}$between 1 and 2 weeks pi $(P=0 \cdot 047)$. Between cell types, the significantly different populations were $\mathrm{CD} 4^{+}$and $\mathrm{CD} 8^{+}$at 2 weeks $(P=$ $0 \cdot 016)$, and TCR $\alpha \beta 1^{+}$and TCR $\alpha \beta 2^{+}$at 1 week pi $(P=$ $0 \cdot 026)$.

\section{Changes in infection and lesions over time}

The progression of infection and lesions over the time course was indicated by bacterial genome titre and tracheal mucosal thickness. The M. gallisepticum genome titre decreased over time as determined by limiting dilutions of M. gallisepticum DNA present in tracheal washes. The bacterial genome titre decreased significantly between 1 and 2 weeks pi $(P=0.029)$ with the titres at 1 and 3 weeks pi also significantly different $(P=0.002)$ (Table 2).

Mucosal thickness increased significantly from week 1 to 2 pi $(P<0.0001)$; however a significant decrease was noted between weeks 2 and $3(P=0.026)$ (Table 2$)$. These data indicated that $M$. gallisepticum multiplication peaked prior to 2 weeks pi, but that lesion development peaked at 2 weeks pi.

\section{DISCUSSION}

\section{Concentration of $\mathrm{CD}^{+}$cells remains constant over time}

The association between infiltrating cell populations and titre of $M$. gallisepticum in the trachea during infection suggests that cell-mediated immunity may play a role in the immune response to this pathogen. Although the nature of the antibody response to $M$. gallisepticum is well established (Roberts et al., 1967), little is known of the cellular immune response initiated by this pathogen. The use of immunohistochemistry enabled T-cell populations to be quantified and their arrangement within the tissue to be visualized.

Initially, this work examined the response to infection along the length of the trachea. To determine any relationship between cellular infiltrates and tracheal region, upper, middle and lower sections of trachea were examined. $\mathrm{CD} 8^{+}$lymphocytic infiltrates were not found to differ significantly between the three sites, indicating that infection was not localized and extended uniformly along the upper respiratory tract.

The infiltration of $\mathrm{CD}^{+}$or $\mathrm{T}$ helper cells into the trachea was expected due to their integral role in the immune response to bacterial pathogens. Numbers of $\mathrm{CD}^{+}$cells remained constant over the 3 week time course, indicating that infiltration occurs early in infection with antibody production (as measured by serum-agglutinating antibodies) initiated and detectable by 2 weeks pi. It is expected that $\mathrm{CD} 4^{+}$cells would also 

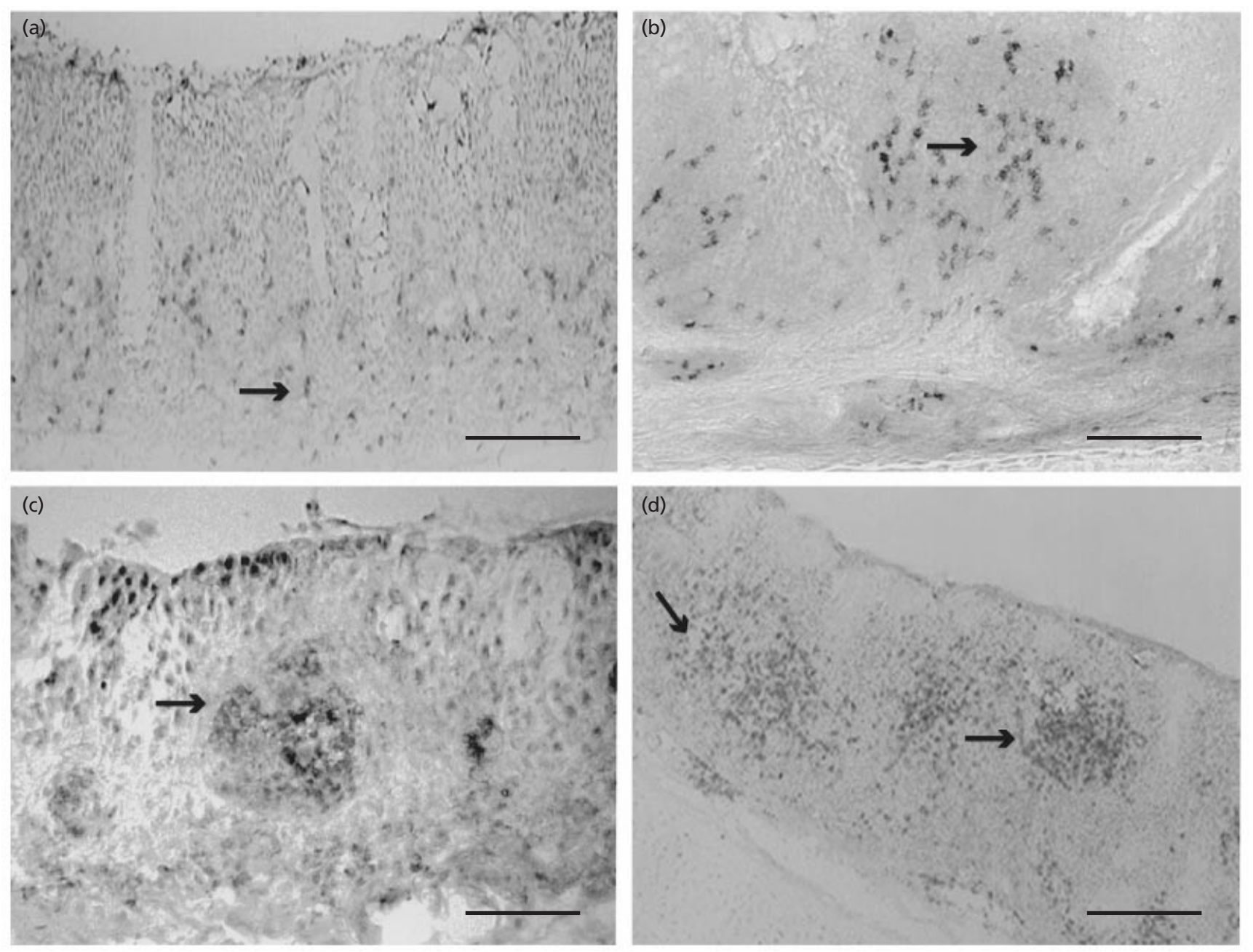

Fig. 2. Immunohistochemical staining for $T$ cell markers in the chicken tracheal epithelium 2 weeks pi. Areas of positive staining are indicated by arrows. (a) $\mathrm{CD}^{+}$cells spread randomly throughout the mucosa. (b) $\mathrm{CD} 8^{+}$cells in a follicular-like cluster in the mucosa. (c) TCR $\alpha \beta 1^{+}$cells within a follicle in the mucosa. (d) TCR $\alpha \beta 2^{+}$cells both within a follicle and in the surrounding tracheal mucosa. Bars, $100 \mu \mathrm{m}$.

Table 2. Bacterial genome titre and mucosal thickness in the tracheas of chickens infected with $M$. gallisepticum

Data in the same column with different superscript letters are significantly different. Data are expressed as mean \pm SEM.

\begin{tabular}{|lll|}
\hline $\begin{array}{l}\text { Weeks } \\
\text { pi }\end{array}$ & $\begin{array}{c}\log _{10} \text { bacterial } \\
\text { genome titre }\end{array}$ & $\begin{array}{c}\text { Mucosal } \\
\text { thickness }(\mu \mathrm{m})\end{array}$ \\
\hline 1 & $2 \cdot 166 \pm 0 \cdot 401^{\mathrm{a}}$ & $145 \cdot 63 \pm 10 \cdot 05^{\mathrm{a}}$ \\
2 & $1 \cdot 000 \pm 0 \cdot 377^{\mathrm{b}}$ & $277 \cdot 34 \pm 15 \cdot 57^{\mathrm{b}}$ \\
3 & $0 \cdot 428 \pm 0 \cdot 297^{\mathrm{b}}$ & $236 \cdot 40 \pm 14 \cdot 15^{\mathrm{c}}$ \\
\hline
\end{tabular}

* Titre shown is the highest tenfold dilution of extracted DNA for which a PCR product could be detected.

be directing other immune responses such as phagocytosis by macrophages and possibly differentiation of other cells through cytokine production.

\section{High concentrations of $\mathrm{CD}^{+}$cells, often in follicular arrangements}

Interestingly, this work also showed infiltration of $\mathrm{CD} 8^{+}$ $\mathrm{T}$ cells in numbers comparable to $\mathrm{CD}^{+}$cells at week 1 pi. The number of $\mathrm{CD} 8^{+}$cells was greatest at this time point with concentrations dropping significantly at 2 weeks (Fig. 1), suggesting that infiltration and recruitment of these cells occurs in the first two weeks of infection. Although numbers increased slightly at 3 weeks, the change was not significant. Peak $\mathrm{CD} 8^{+}$cell numbers corresponded to peak titres of M. gallisepticum DNA in the trachea, suggesting recruitment during acute infection. The decrease in mycoplasma titre was then followed by a significant decrease in mucosal thickness by 3 weeks pi. Particularly notable in the $\mathrm{CD}^{+}$response was the arrangement of these cells in follicular-like patterns in the mucosa, suggesting their specific involvement in the follicular lymphoproliferative lesions typical of respiratory- 
tract infections caused by $M$. gallisepticum and $M$. pneumoniae. While the significance of these clusters in development of immunity is unknown, it could suggest that $\mathrm{CD}^{+}$cells are attracted to foci of infection and contribute to lesion formation in the trachea. The function of the $\mathrm{CD} 8^{+}$cells could not be determined in this study. They may play a role as cytotoxic cells, or alternatively in the production of cytokines.

\section{$\mathrm{CD}^{+}$and $\mathrm{CD}^{+}$cells are TCR $\alpha \boldsymbol{\beta}$, not $\gamma \delta$}

Three T-cell receptors (TCRs), TCR $\gamma \delta, \alpha \beta 1$ and $\alpha \beta 2$, involved in antigen-MHC (major histocompatibility complex) recognition, have been characterized in the chicken. All three were examined in this study. TCR $\gamma \delta$ is a receptor found on $\mathrm{CD}^{-} \mathrm{CD}^{-} \mathrm{T}$ cells in the blood and thymus. However, following migration into the spleen and intestine, the majority of these cells become $\mathrm{CD} 8^{+}$ (Chen et al., 1988). It is believed that TCR $\gamma \delta$ cells preferentially colonize the surface epithelium and are able to elicit cytotoxic responses as shown in other species. TCR $\alpha \beta 1$ and TCR $\alpha \beta 2$ consist of alpha and beta chains, with TCR $\alpha \beta 1$ the receptor on the majority of T cells, accounting for $40-50 \%$ of thymocytes, splenocytes and blood monocytes. TCR $\alpha \beta 2$ is unique to avian species and accounts for $9 \%$ of thymocytes, $15-25 \%$ of blood monocytes and $13 \%$ of splenocytes. Of the TCR $\alpha \beta 2^{+}$ cells in the blood and spleen, approximately $80 \%$ are $\mathrm{CD}^{+}{ }^{+} \mathrm{CD} 8^{-}$cells and $20 \%$ are $\mathrm{CD} 4^{-} \mathrm{CD} 8^{+}$(Char et al., 1990; Chen et al., 1989). M. gallisepticum did not appear to stimulate infiltration of TCR $\gamma \delta$ cells into the trachea, with the response instead appearing to be mediated by $\alpha \beta$ receptors. The function of avian T cells bearing different types of $\alpha \beta$ receptors is currently unknown.

As with CD $8^{+}$cells, numbers of TCR $\alpha \beta 1^{+}$and TCR $\alpha \beta 2^{+}$ cells peaked within the first 2 weeks of infection. $\mathrm{TCR} \alpha \beta 1^{+}$cell concentrations were significantly higher $(P<0 \cdot 05)$ at 2 weeks compared with 1 week whilst TCR $\alpha \beta 2^{+}$cell concentrations were higher at 1 week pi $(P<0.05)$ compared to 2 weeks pi; the slight increase at 3 weeks was not found to be significant (Fig. 1). Such a change in the numbers of TCRs may suggest a shift in the infiltrating populations of $\mathrm{CD}^{+}$and $\mathrm{CD}^{+}$ cells from TCR $\alpha \beta 1^{+}$to TCR $\alpha \beta 2^{+}$during the course of infection. Further investigation is required to determine the significance of such a change as well as the specific cell types involved.

\section{A population of TCRO cells?}

The total number of $\mathrm{TCR}^{+}$cells was significantly lower than the sum of $\mathrm{CD}^{+}$and $\mathrm{CD} 8^{+}$cells at weeks 1 and 2, indicating that a population of TCR $0 / \mathrm{CD}^{+}$or TCR0/ $\mathrm{CD} 8^{+}$cells was infiltrating the trachea. A population of TCR0/CD8 ${ }^{+}$, but not TCR0/CD $4^{+}$, has been described in the chicken. It has been suggested that these cells express similar cytotoxic activity to natural killer cells, raising the possibility that such cells may be part of the response to mycoplasma infections (Bucy et al., 1990; Gobel et al., 1994).
A population of $\mathrm{CD}^{+} / \mathrm{TCR} 0$ cells infiltrating the trachea could be further supported if the chain specificity of the anti-CD8 monoclonal antibody was known. CD8 may occur as an $\alpha \alpha$ homodimer or an $\alpha \beta$ heterodimer. $\mathrm{CD} 8 \alpha \beta$ is found on cytotoxic T cells while CD $8 \alpha \alpha$ is found on a number of small subsets including TCR0 NK cells (Abbas et al., 1991). The chain specificity of the antibody used in this work is currently unknown. If it does bind only to the $\alpha$ chain then we have most likely detected all $\alpha \alpha$ cells but may not have detected some $\alpha \beta$ cells, as studies comparing two other anti-chicken CD8 monoclonal antibodies have shown differential binding of the CD $8 \alpha$ molecule (Breed et al., 1996).

\section{Basis for stimulation of $\mathrm{CD8}^{+}$cells by mycoplasmas}

As shown in Table 1, some variation in cell concentrations was seen between birds within the same group. This discrepancy may be due to the small amount of tissue examined in frozen sections. Further work using fluorescence-activated cell-sorting analysis, allowing a large number of cells to be examined at one time, in addition to double staining, may answer many of the questions raised in this work concerning the exact nature of the cell populations detected.

These results suggest that $\mathrm{CD} 8^{+}$cells may be part of the primary response to $M$. gallisepticum infection, occurring mainly in the acute stages of disease, in comparison to the humoral immune response, which is a longer-term response. Although it has long been believed that $\mathrm{CD} 8^{+}$cells responded mainly to viral pathogens, other researchers have shown that a number of bacterial species are also able to stimulate these cells by a variety of mechanisms. Superantigens produced by $M$. arthritidis and other bacteria have been shown to directly bind to MHC class II cells outside the peptidebinding groove and then interact with the TCR causing stimulation (Fleischer et al., 1991). CD8 ${ }^{+}$responses have also been shown to result from intracellular infections by bacterial pathogens, and have been correlated with escape of these organisms from the phagosome and then persistence in the cytoplasm, allowing degradation of antigens and presentation in association with MHC class I (Hess et al., 1996). While it is unlikely that such a mechanism could explain the response induced by $M$. gallisepticum, as there is no evidence that it persists within the cytoplasm of host cells, the potential of mycoplasma membranes to fuse with the host-cell membrane (Franzoso et al., 1993) may result in the introduction of cytoplasmic mycoplasma antigens directly into the cytoplasm of host cells, thus enabling their presentation to $\mathrm{CD} 8^{+}$lymphocytes. Further studies to detect mycoplasmas in respiratory lesions using methods such as confocal microscopy may explain the presence of $\mathrm{CD} 8^{+}$cells and their possible role in response to infection.

Whatever the mechanism of stimulation, it is clear that $\mathrm{CD}^{+} \mathrm{T}$ cells may play a significant role in the pathogenesis of M. gallisepticum infections, and given their arrangement in the mucosa could play a key role in 
the development of follicular lesions in the tracheal mucosa.

\section{Conclusion}

In conclusion, this analysis of infiltrating lymphocytes in $M$. gallisepticum infection has raised additional questions about the role of cell-mediated immunity in mycoplasma infections. Further examination of the response to the attenuated vaccine strain of M. gallisepticum and the $\mathrm{T}$ cell response of vaccinated birds after challenge may provide some indication of the role of $\mathrm{CD}^{+}$cells in development of immunity to mycoplasma infections. The role of $\mathrm{CD} 8^{+}$cells in other mycoplasma infections also requires examination.

\section{ACKNOWLEDGEMENTS}

The authors would like to thank Michelle Benham for technical assistance.

\section{REFERENCES}

Abbas, A. B., Lichtman, A. H. \& Pober, J. S. (1991). Cellular and Molecular Immunology. Philadelphia, PA: W. B. Saunders.

Avakian, A. P. \& Ley, D. H. (1993). Protective immune response to Mycoplasma gallisepticum demonstrated in respiratory-tract washings from M. gallisepticum-infected chickens. Avian Dis 37, 697-705.

Boyle, J. S. \& Morrow, C. J. (1994). Phylogeny of avian mycoplasmas: implications for mollicute taxonomy. In 10th International Congress of the International Organization for Mycoplasmology, pp. 589-590. Bordeaux, France: International Organisation of Mycoplasmology.

Breed, D. G., Carr, P. \& Vermeulen, A. N. (1996). Differential binding of two monoclonal antibodies directed against the chicken CD8 alpha molecule. Vet Immunol Immunopathol 52, 117-125.

Bucy, R. P., Chen, C. H. \& Cooper, M. D. (1990). Development of cytoplasmic $\mathrm{CD}^{+} / \mathrm{T}$ cell receptor-negative cells in the peripheral lymphoid tissues of chickens. Eur J Immunol 20, 1345-1350.

Char, D., Sanchez, P., Chen, C. H., Bucy, R. P. \& Cooper, M. D. (1990). A third sublineage of avian T cells can be identified with a $\mathrm{T}$ cell receptor-3-specific antibody. J Immunol 145, 3547-3555.

Chen, C. H., Cihak, J. \& Cooper, M. D. (1988). Differential expression of two T cell receptors, TcR1 and TcR2, on chicken lymphocytes. Eur J Immunol 18, 539-543.

Chen, C. H., Sowder, J. T., Lahti, J. M., Cihak, J., Losch, U. \& Cooper, M. D. (1989). TCR3: a third T-cell receptor in the chicken. Proc Natl Acad Sci USA 86, 2351-2355.

Chhabra, P. C. \& Goel, M. C. (1980). Normal profile of immunoglobulins in sera and tracheal washings of chickens. Res Vet Sci 29, 148-152.

Cimolai, N., Taylor, G. P., Mah, D. \& Morrison, B. J. (1992). Definition and application of a histopathological scoring scheme for an animal model of acute Mycoplasma pneumoniae pulmonary infection. Microbiol Immunol 36, 465-478.

Cole, B. C. \& Atkin, C. L. (1991). The Mycoplasma arthritidis T cell mitogen, MAM: a model superantigen. Immunol Today 12, 271-276.
Fleischer, B., Gerady-Schahn, R., Metzroth, B., Carrel, S., Gerlach, D. \& Köhler, W. (1991). An evolutionary conserved mechanism of $\mathrm{T}$ cell activation by microbial toxins: evidence for different affinities of $\mathrm{T}$ cell receptor-toxin interaction. J Immunol 146, 11-17.

Franzoso, G., Hu, P.-C., Meloni, G. A. \& Barile, M. F. (1993). The immunodominant 90 -kilodalton protein is localised on the terminal tip structure of Mycoplasma pneumoniae. Infect Immun 61, 1523-1530.

Frey, M. L., Hanson, R. P. \& Anderson, D. P. (1968). A medium for the isolation of avian mycoplasma. Am J Vet Res 29, 2163-2171.

Gobel, T. W. F., Chen, C. H., Shrimpf, J., Grossi, C. E., Bernot, A., Bucy, R. P., Auffray, C. \& Cooper, M. D. (1994). Characterization of avian natural killer cells and their intracellular CD3 protein complex. Eur J Immunol 24, 1685-1691.

Hess, J., Gentschev, I., Miko, D., Welzel, M., Ladel, C., Goebel, W. \& Kaufmann, S. H. (1996). Superior efficacy of secreted over somatic antigen display in recombinant Salmonella vaccine induced protection against listeriosis. Proc Natl Acad Sci USA 93, 1458-1463.

Kuwano, K., Ono, S., Akashi, A., Ohishi, M., Shigematsu, H. \& Arai, S. (1997). Production of a T-cell clone which reacts with membrane proteins of Acholeplasma laidlawii. Microbiol Immunol 41, 261-264.

Lai, W. C., Bennett, M., Lu, Y.-S. \& Pakes, S. P. (1991). Vaccination of Lewis rats with temperature-sensitive mutants of Mycoplasma pulmonis: adoptive transfer of immunity by spleen cells but not by sera. Infect Immun 59, 346-350.

Mukherjee, F., Tiwary, B. K., Prasad, R. L., Jha, G. J. \& Roy, M. K. (1990). Role of T and B cells in immune response to Mycoplasma gallisepticum infection in normal and immunocompromised chickens. Indian J Anim Sci 60, 1027-1031.

Nunoya, T., Tajima, M., Yagihashi, T. \& Sannai, S. (1987). Evaluation of respiratory lesions in chickens induced by Mycoplasma gallisepticum. Jpn J Vet Sci 49, 621-629.

Roberts, D. H., Olesiuk, O. M. \& Van Roekel, H. (1967). Immunological response of fowl to Mycoplasma gallisepticum and its relationship to latent infection. Am J Vet Res 28, 1135-1152.

Simecka, J. W., Davis, J. K., Davidson, M. K., Ross, S. E., Stadtlander, C. T. K.-H. \& Cassell, G. H. (1992). Mycoplasma diseases of animals. In Mycoplasmas: Molecular Biology and Pathogenesis, pp. 391-415. Edited by J. Maniloff. Washington, DC: American Society for Microbiology.

Sykes, J. E., Studdert, V. P. \& Browning, G. F. (1998). Detection and strain differentiation of feline calicivirus in conjunctival swabs by RT-PCR of the hypervariable region of the capsid protein gene. Arch Virol 143, 1321-1334.

Tiwary, B. K. \& Goel, M. C. (1986). Experimental Mycoplasma gallisepticum infection in normal, IgA- and CMI-deficient chickens. Indian J Anim Sci 56, 719-725.

Whithear, K. G. (1993). Avian mycoplasmosis. In Australian Standard Diagnostic Techniques for Animal Diseases, pp. 1-12. Edited by L. A. Corner \& T. J. Bagust. Melbourne: Commonwealth Scientific and Industrial Research Organsation for the Standing Committee on Agriculture and Resource Management. Whithear, K. G., Harrigan, K. E. \& Kleven, S. H. (1996). Standardised method of aerosol challenge for testing the efficacy of Mycoplasma gallisepticum vaccines. Avian Dis 40, 654-660.

Received 9 September 1999; revised 6 December 1999; accepted 8 February 2000. 